\title{
The Radiobasilic Transposition on the Upper Arm
}

\author{
Üst Kolda Radyobazilik Transpozisyon
}

\begin{abstract}
Aim: The ideal vascular access for hemodialysis is through autologous arteriovenous fistulas that are from the distal to the proximal in the upper extremity. Using the brachial artery as the inflow artery increases the risk of developing complications, especially steal syndrome. In this study we aimed to explain the results of the arteriovenous fistulas that we performed with the technique of radiobasilic vein transposition that originated from the radial artery in the upper arm.

Materials and Methods: Forty patients who had undergone radio-basilic transposition arteriovenous fistula operation between January 2009 and December 2012 were included in this retrospectively study. The recorded postoperative complications included steal syndrome, venous hypertension, and aneurysm.

Results: In the follow-up period three patients developed aneurism. Steal syndrome and venous hypertension were observed in none of the patients. The mean follow-up duration was $28.99 \pm 1.57$ months. The one-year and two-year primary (and secondary) patency rates were $76.6 \%$ and $49.5 \%$ (and $81.4 \%$ and $55.6 \%$ ), respectively.

Discussion and Conclusion: Steal syndrome is more frequently observed in arteriovenous fistulas that originate from brachial artery than from radial artery. Many researchers used the proximal radial artery as the inflow artery in order to avoid complications. We conclude that basilic vein transposition is safer against steal syndrome especially when performed as radiobasilic transposition arteriovenous fistula, and that the patency rates are coherent with the literature. However, we believe that comparative studies are needed.

Keywords: Arteriovenous fistula; hemodialysis; basilic vein transposition
\end{abstract}

\section{Öz}

Amaç: Hemodiyaliz için ideal giriş yolu üst ekstremitede distalden proksimale doğru olan otolog arteryovenöz fistüllerdir. Brakiyal arteri giriş arteri olarak kullanmak, özellikle steal sendromu olmak üzere komplikasyon riskini attırır. Bu çalışmada üst ekstremitede radyal arterden orijin alan radyobazilik ven transpozisyonu tekniği ile yaptığımız arteryovenöz fistüllerin sonuçlarını açıklamayı amaçladık.

Gereç ve Yöntemler. Bu retrospektif çalışma, Ocak 2009 - Aralık 2012 döneminde radyobazilik transpozisyon arteryovenöz fıstül yaptığımız kırk hastayı kapsamaktadır. Steal sendromu, venöz hipertansiyon ve anevrizma gibi postoperatif komplikasyonlar kaydedildi.

Bulgular. Takip süresince üç hastada anevrizma gelişti. Hastaların hiçbirinde steal sendromu ve venöz hipertansiyon görülmedi. Ortalama takip süresi $28,99 \pm 1,57$ ay idi. Bir yıllık ve iki yıllık primer açık kalma oranları sırası ile $\% 76,6$ ve \%49,5 idi. Bir yıllık ve iki yıllık sekonder açık kalma oranları ise sırası ile \%81,4 ve \%55,6 idi.

Tartışma ve Sonuç: Steal sendromu brakiyal arterden orijin alan arteryovenöz fistüllerde radyal arterden orijin alan arteryovenöz fistüllere göre daha fazla görülür. Pek çok araştırmacı komplikasyonlardan kaçınmak için giriş arteri olarak proksimal radyal arteri kullanılmıştır. Sonuçta özellikle RBAVF şeklinde yapılan bazilik ven transpozisyonunun steal sendromu açısından daha güvenli olduğunu ve patensi oranlarının da literatür ile uyumlu olduğunu düşünüyoruz. Bununla birlikte karşılaştırmalı çalışmaların gerektiğine inanıyoruz.

Anahtar Sözcükler. Arteryovenöz fistül; hemodiyaliz; bazilik ven transpozisyonu
Okay Güven Karaca', Mehmet Ali Sungur ${ }^{2}$, Ayşegül Koç ${ }^{1}$

Deparment of Cardiovascular Surgery, Medical Faculty of Duzce University, Duzce, Turkey

2 Department of Biostatistics and Medical Informatics, Medical Faculty of Duzce University, Duzce, Turkey
Geliş Tarihi /Received : 14.10.2016 Kabul Tarihi /Accepted: 27.11.2016

DOI: 10.21673/anadoluklin.284863

Sorumlu Yazar/Corresponding Author Okay Guven Karaca, MD

Duzce Universitesi, Tıp Fakültesi,

Kalp Damar Cerrahisi ABD, Konuralp Yerleskesi, 81620, Duzce, Turkey

E-mail:drguven@gmail.com 


\section{INTRODUCTION}

Chronic renal failure is a serious health problem with its morbidity, mortality and increased costs. For patients who undergo hemodialysis therapy, having the most appropriate vascular access is very important. Among hemodialysis strategies such as autologous AVFs (arteriovenous fistulas), prosthetic graft AVFs or central venous catheters, the autologous AVFs are suggested firstly by guidelines (1-3). The ideal vascular access is the autologous AVF (arteriovenous fistula) that is placed from distal to proximal on the upper arm (1-3). Progressing to the proximal side, AVF procedures originate from brachial artery as the inflow artery, but this situation has increased risks for complications than the vascular accesses that originate from the radial artery (4-6). When the basilic vein transposition technique was first described, it originated from brachial artery $(7,8)$. However, it was subsequently performed by different techniques by many authors (9-13). Especially with the aim of avoiding the complications such as steal syndrome, proximal radial artery was used by many surgeons $(14,15)$. In this study, we aimed to report the results of the AVFs that were performed with radiobasilic transposition arteriovenous fistula (RBAVF) technique that originated from the proximal radial artery.

\section{MATERIALS AND METHODS \\ Patients}

The approval of Düzce University Local Ethics Committee was obtained. In this retrospectively conducted study, all patients had undergone an access procedure in the upper arm previously. All patients had one or more failed operations of the forearm such as snuffbox, Cimino-Brescia or antecubital radiocephalic AVF or no suitable forearm veins were found at their Doppler ultrasonographic examinations (USG). We used our institutional operative record/database to identify 40 patients who had undergone radiobasilic transposition AVF between January 2009 and December 2012. Data were obtained from inpatient charts, outpatient records, operating room notes, dialysis records and phone calls, retrospectively. Postoperative complications of the patients such as steal syndrome, venous hypertension and aneurysm were recorded.
Vascular Doppler USG was performed in all patients for the purpose of mapping prior to the operation. The results of the Doppler USG revealed that the diameter of the basilic vein $\geq 2.5 \mathrm{~mm}$, the diameter of brachial artery $\geq 3 \mathrm{~mm}$ and the diameter of radial artery $\geq 2$ $\mathrm{mm}$. It was noted that there was no significant stenosis on the traces of either artery or vein. Four to six weeks following the operation, Doppler USG was performed on the AVF in order to check its maturation.

\section{Operations}

All RBAVFs were performed as one-stage procedures under combined anesthesia (Bupivacaine and Lidocaine). Two separate incisions were used to identify the basilic vein. Firstly, a long longitudinal incision was performed superiorly on the medial epicondyle to extend to the axilla. Basilic vein was mobilized for more than $10 \mathrm{~cm}$ on the upper arm, starting from the axilla (Figure 1a). Care was taken to avoid damage to the medial antebrachial cutaneous nerve of the upper arm (Figure $1 \mathrm{~b}$ ). The second separate small longitudinal incision was started just below the medial epicondyle of the humerus and was extended laterally and inferiorly (Figure 1c). The basilic vein was $5-7 \mathrm{~cm}$. further mobilized on the forearm (Figure 1c). Median cubital vein was ligated (Figure 1d). The basilic vein was dissected completely free and the branches were ligated using a simple tie or a suture ligature based on the size of the branches (Figure 2). Thus a long basilic vein was obtained (Figure 2). Third short transverse incision was performed on antecubital fossa. The brachial artery, radial artery and ulnar artery were exposed and controlled with vessel loops. Attention was paid to avoid injury to the median nerve which lied adjacent to the artery. A mini incision was made for subcutaneous tunnel on the upper arm. Then, the subcutaneous tunnel was prepared on the upper arm. The basilic vein was gently dilated with heparinized saline, marked to help maintain the proper orientation, and wrapped with a heparin-soaked sponge. The basilic vein was carefully tunneled by using a curved vascular clamp. The vein should be tunneled directly below the skin through the underlying fascia between both the antecubital and axillary ends of the incision. The patients were systematically heparinized (5000 units of unfractionated heparin, intravenously) and the brachial bifurcation (brachial, radial, ulnar artery) was 
Table 1. Demographic and clinical characteristics of patients

\begin{tabular}{lc}
\hline & RBAVFs $(\mathbf{n}=\mathbf{4 0})$ \\
\hline Age & $54.20 \pm 14.64(28-90)$ \\
\hline Female & $20(50.0 \%)$ \\
\hline Non-dominant arm & $35(87.5 \%)$ \\
\hline Comorbidity & $26(65.0 \%)$ \\
\hline \multicolumn{1}{c}{ DM } & $19(47.5 \%)$ \\
\hline HT & $18(45.0 \%)$ \\
\hline Cholesterol & $3(7.5 \%)$ \\
\hline Diameter of vein $(\mathbf{m m})$ & $4.17 \pm 0.53(3.1-5.1)$
\end{tabular}

RBAVF: Radiobasilic arteriovenous fistula, DM: Diabetes mellitus, HT: Hypertension

Table 2. Postoperative variables

\begin{tabular}{lc}
\hline & RBAVF $(\mathbf{n}=\mathbf{4 0})$ \\
\hline Successful hemodialysis & $40(100.0 \%)$ \\
\hline Number of previous AVFs & $2.425(2-4)$ \\
\hline Patency of AVF & $22(55.0 \%)$ \\
\hline Any complication & $3(7.5 \%)$ \\
\hline Steal & $0(0.0 \%)$ \\
\hline VHT & $0(0.0 \%)$ \\
\hline Aneurysm & $3(7.5 \%)$ \\
\hline Exitus & $5(12.5 \%)$ \\
\hline
\end{tabular}

Doppler USG (ml/min)

$849.50 \pm 300.87(430-1800)$

RBAVF: Radiobasilic arteriovenous fistula, AVF: Arteriovenous fistula, VHT: Venous hypertension

mobilized for several centimeters. Vascular clamps were placed. Arteriotomy was made in such a way that approximately $1 / 3$ of the incision was on the brachial artery and $2 / 3$ of the incision was on the radial artery. The basilic vein was anastomosed end-to-side to the brachial bifurcation using 7/0 polypropylene (Figure 3). Following this procedure, the thrill was palpated. A closed- suction drain was placed in the dissected bed of the basilic vein and brought out through a separate stab incision. The subcutaneous tissues and skin were closed with an absorbable suture.

\section{Follow-Up}

Postoperatively, in order to check whether the arteriovenous fistula functioned sufficiently, the thrill was palpated in all patients. On the $14^{\text {th }}$ day following the operation, patients were called for control and removal of the sutures. Then, the patients were called again, after 4-6 weeks, in order to check the maturation of the fistula. The flow of the arteriovenous fistula was checked with the Doppler USG. Maturation was defined as the time the blood flow of the fistula was over $600 \mathrm{ml} / \mathrm{min}$. and the primary fistula was suitable to allow successful cannulation.

Mechanical thrombectomy was performed for the occluded arteriovenous fistulas. Low molecular weight heparin and warfarin was administered to the patients while patency was provided with mechanical thrombectomy. The patients in whom patency was not provided were excluded from the follow-up.

Endpoints included primary patency and secondary patency. The different patency rates were defined as described by Sidawy et al. (16). Primary patency was defined as the interval from the time of fully functional access placement until any intervention designed to maintain or reestablish patency, access thrombosis, or the time of measurement of patency. Secondary patency was defined as the interval from the time of fully functional access placement until access abandonment, thrombosis or the time of patency measurement including intervening manipulations designed to reestablish functionality in thrombosed access.

The patients in whom the thrill of the arteriovenous fistula was lost, the patients who could not enter the hemodialysis with their arteriovenous fistula, the patients who died and the kidney transplant patients were excluded from follow-up.

\section{Statistical Analysis}

Patients' demographic factors were compared by using Fisher's Exact and $\chi^{2}$ test for categorical variables and $t$ test for continuous variables. Fistula patency, fistula survival and patient survival were analyzed by using life tables and Kaplan-Meier survival analysis. Statistical analysis was performed with PASW v.18 software package. A $p$ value of $<0.05$ was considered statistically significant. Data were presented as mean \pm standard error of mean.

\section{RESULTS}

During the study period, 40 radiobasilic vein transposition AVFs were created. It is noteworthy that all patients underwent tertiary access procedures and tolerated them well. There was no intraoperative mortality. All patients could receive hemodialysis therapy with the AVFs that was placed. The mean age of RBAVF group was $54.20 \pm 14.64$ (28-90) years. De- 


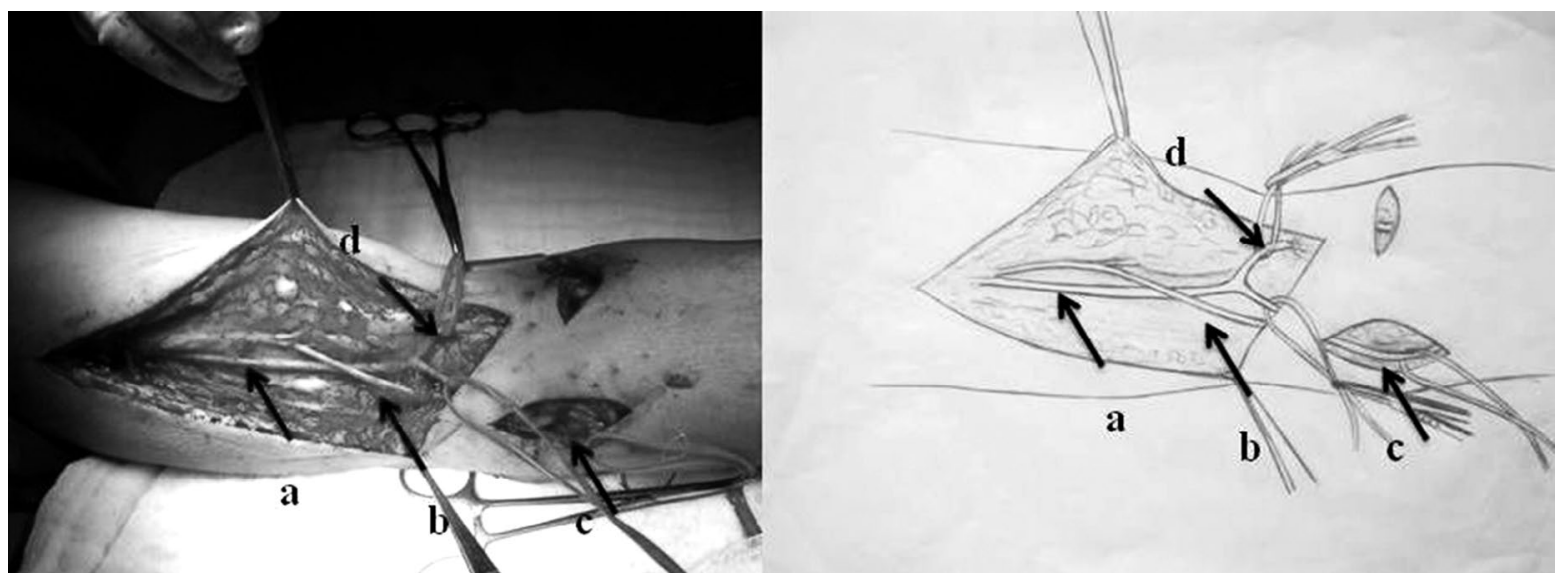

Figure 1. a) The basilic vein b) The medial antebrachial cutaneous nerve c) The basilic vein on the forearm d) The median cubital vein

mographic and clinical characteristics were presented in Table 1.

During the follow-up period, three of the patients $(7.5 \%)$ had aneurysm. Steal syndrome and venous hypertension were observed in none of the patients (Table 2).

Mean follow-up period was $28.99 \pm 1.57$ months. Primary patencies at one and two years of follow-up were $76.6 \%$ and $49.5 \%$, respectively (Figure 4 ). Secondary patencies were $81.4 \%$ and $55.6 \%$, respectively (Figure 5). Also, the effects of gender, operation in non-dominant arm, hypertension, cholesterol and diabetes mellitus on the patency were not significant.

\section{DISCUSSION}

For hemodialysis related to End-Stage Renal Disease (ESRD), first arteriovenous (AV) access was cre- ated by Quinton and colleagues inserting Silastic tubes with Teflon tips into radial artery and cephalic vein in 1960 (17). The first access was called as Shibner shunt and it had some disadvantages such as being uncomfortable and having high infection and bleeding risks. Brescia, Cimino and Appel in 1966 reported the use of a surgically created subcutaneous arteriovenous fistula at the wrist (18). With this new autogenous fistula, the risks of bleeding and infection were avoided. However, in the following years, with recipes of autogenous and non-autogenous AVFs, such new and more complex complications like arterial steal syndrome, ischemic monomelic neuropathy, venous hypertension, aneurysm, thrombosis began to be reported. In the literature, the incidence of aneurysm formation in autogenous arteriovenous fistula (AVF) has been reported to be as high as $30 \%$, the majority of which occurring in the upper arm (19). In our study, aneurysm forma-
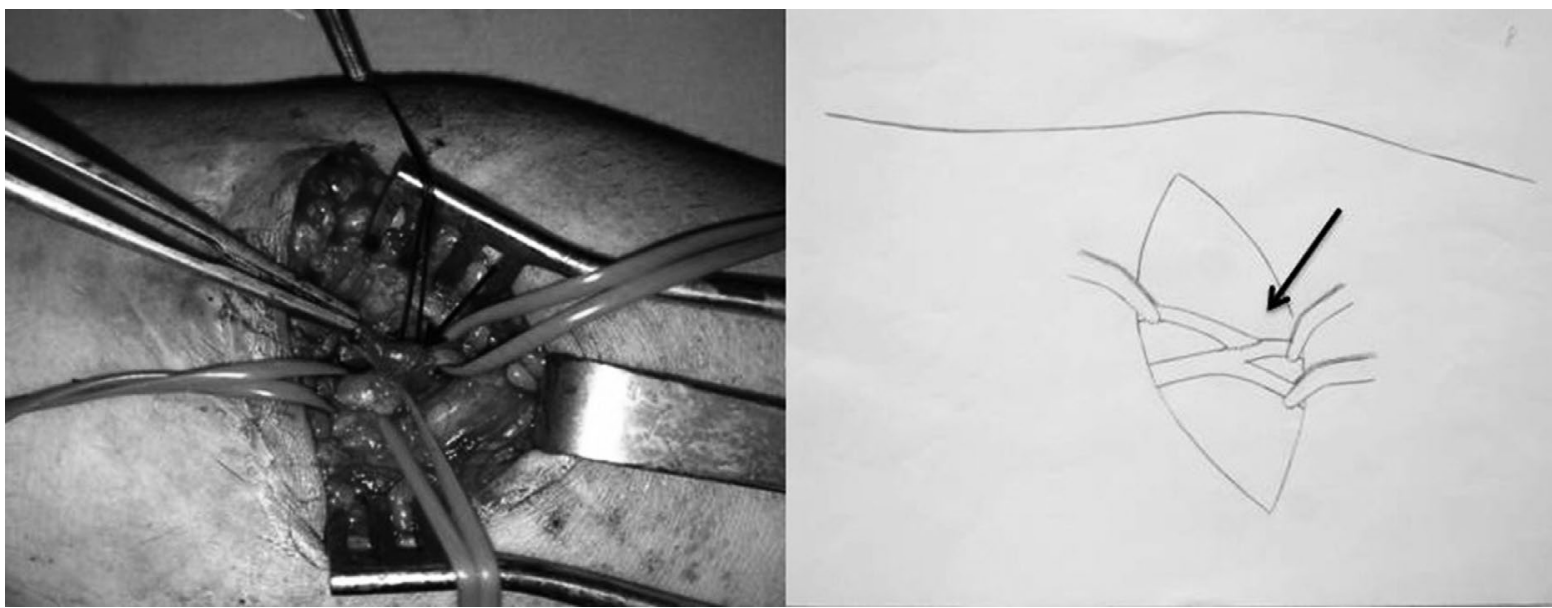

Figure 2. A long basilic vein 


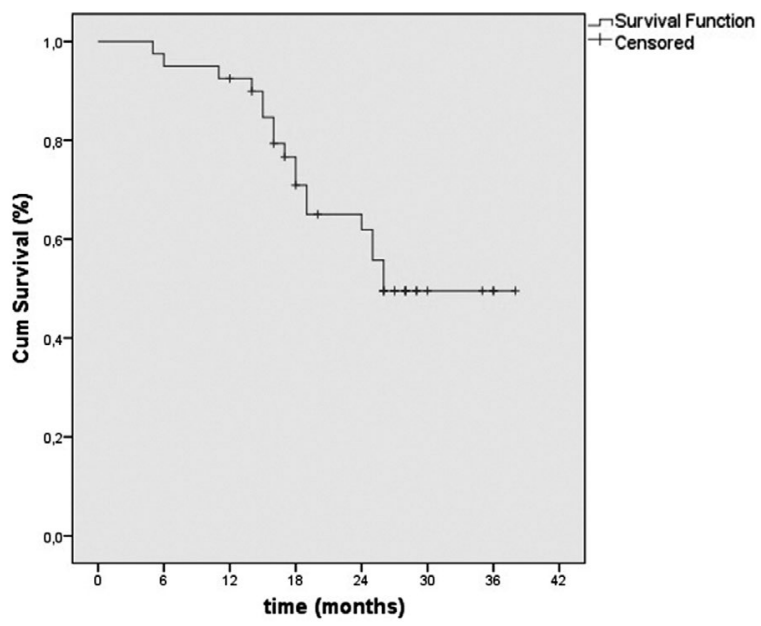

Figure 4. Primary patency rates of patients with radiobasilic (RBAVF) fistulas

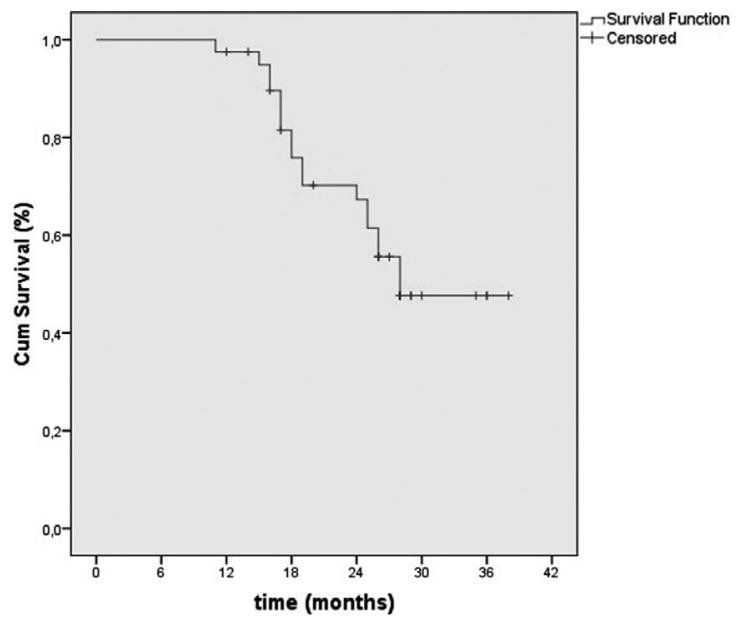

Figure 5. Secondary patency rates of patients with radiobasilic (RBAVF) fistulas

tion was observed with an incidence of $7.5 \%$, which was consistent with the literature. Two patients who have aneurysm formation was puncture side pseudoaneurysm. One patient who has aneurysm formation was diffuse enlargement of AVF. Additionally, venous hypertension was not present in any of our patients.

In patients who undergo hemodialysis for a long time because of chronic renal failure, secondary and tertiary AVF are needed. More than one guideline propose the autologous AVFs (1-3). Vascular Access Workgroup suggests wrist (radiocephalic), elbow (brachiocephalic) and transposed brachiobasilic autologous AVF respectively (1). Similarly, we had also preferred wrist (radiocephalic), elbow (as much as possible radiocephalic) and transposed basilic (proxi- mal radial basilic) AVFs, respectively. Basilic vein transposition technique is more complicated than the other autologous AVF techniques, but especially in recent years, it is preferred by more surgeons having increased surgical experience.

Basilic vein remains superficially in the forearm. After passing antecubital fossa, while it progresses proximally, it proceeds deeper in parallel with the brachial artery. But anatomical variations can exist regarding the brachial and basilic veins. As a result of these variations, some cases who had complications and who had failed were reported among patients in whom basilic vein transposition had been made (20). Javier et al. classified the anatomy of basilic and brachial veins in the upper arm and divided into three groups. In Type 1 anatomy (66\%), the basilic vein joins the brachial venous system to form the axillary vein. In Type 2 and 3 anatomies, the basilic vein joins the brachial venous system in the middle or lower third of the upper arm. In Type 2 (17\%), the brachial veins are still paired at the level of the brachial-basilic junction. In Type 3 anatomy (17\%), there is only a single unpaired brachial vein above the level of convergence with the basilic vein (21). In this publication, Javier et al. proposed and stated that identifying the type 3 anatomy by preoperative vascular mapping can reduce the complications (21). In our study, the continuity of the basilic vein under the elbow was observed in the patients in Type 1 and 2 groups whose basilic veins were conveniently located by preoperative mapping. In all appropriate patients, basilic vein was mobilized from axillary region to proximal $1 / 3$ of the forearm, as we have already described (Figure 2 and 3). Then it was anastomosed to the proximal part of the radial artery.

Since its first description in 1970, the basilic vein transposition AVF has been performed with several different techniques such as one-stage procedure, twostage procedure (elevation and transposition), keyhole technique and video-assisted transposition (9-13). However, in all these techniques, basilic vein was issued down to the elbow and generally was anastomosed to the brachial artery.

With creating autologous or prosthetic arteriovenous fistula by doing an anastomosis between an artery and a vein, a high flow, low-resistance circuit is 
created. Blood flow is preferred to be directed through the venous part of the arteriovenous fistula, due to the pressure differential (22). In fact, to create an arteriovenous fistula results in a decrease in the ipsilateral digital pressures in approximately $80 \%$ of patients (23). This 'physiological steal' is generally well tolerated, but due to ischemic symptoms, it begins to be clinically symptomatic when compensatory mechanisms are insufficient. Symptoms are sensory loss and paresthesia, weakened or absent hand pulses, muscle weakness, rest pain during dialysis, muscle atrophy, ulceration or gangrene of digits. Steal symptoms are classified as; grade 0 , grade 1 (mild), grade 2 (moderate), grade 3 (severe). Grade 2 and 3 might be operated. Risk factors of steal syndrome are female gender, age, peripheral arteriosclerosis, diabetes, multiple operations on the same limb, use of brachial artery or high flow AVFs (4-6). As we have already pointed out, risk of steal syndrome is higher in the AVFs that originate from brachial artery when compared to AVFs that originate from radial artery. With the aim of avoiding the complications, proximal radial artery was used as the inflow artery by various authors $(14,15)$. The major disadvantage of radiocephalic AVFs is the lower blood flow rate (1). With this aim, we extended a part of the anastomosis (proximal 1/3) to the brachial artery in the RBAVFs. With this process, we aimed to have sufficient patency and to avoid the complications by using radial artery. Steal syndrome was observed in none of the patients. In the literature, the patency rates of basilic vein transposition have been reported to be within a wide range. There have been authors reporting the one-year primary patency rates between 23\% and $90 \%$ and secondary patency rates between $47 \%$ and $96 \%$ (24). Also we observed that, in terms of patency and the flow rate of the fistula, there was no significant difference in the literature.

In conclusion, the patients who receive hemodialysis therapy due to end stage renal failure need a lot of additional initiatives. We think that basilic vein transposition technique, when especially performed as RBAVF, is more reliable and the patency rates are consistent with the literature. However, we believe that comparative studies are needed.

\section{REFERENCES}

1. Clinical practice guidelines for vascular access. Vascular Access Workgroup. (National Kidney Foundation's KDOQI 2006 Vascular Access Guidelines). Am J Kidney Dis. 2006:48:227-350.

2. Sidawy AN, Spergel LM, Besarab A, et al. The Society for Vascular Surgery: clinical practice guidelines for the surgical placement and maintenance of arteriovenous hemodialysis access. J Vasc Surg. 2008;48:2-25.

3. Fistula First: National Vascular Access Improvement Initiative. [Revised 2009; cited 18 December 2010]. Available at: http://www.fistulafirst.org/. Accessed 1 June 2010.

4. Tordoir JHM, Dammers R, van der Sande FM. Upper extremity ischemia and hemodialysis vascular access. Eur J Vasc Endovasc Surg. 2004;27:1-5.

5. Matolo N, Kastagir B, Stevens LE, et al. Neurovascular complications of brachial arteriovenous fistula. Am J Surg. 1971;121:716-9.

6. Lazarides MK, Staramos DN, Panagopoulos GN, et al. Indications for surgical treatment of angioaccess-induced arterial “steal.” J Am Coll Surg. 1998;187:422-6.

7. Cascardo S, Acchiardo S, Beven EG, et al. Proximal arteriovenous fistulae for hemodialysis when radial arteries are unavailable. Proc Eur Dial Transplant Assoc. 1970;7:42-6.

8. Dagher F, Gelber R, Ramos E, et al. The use of basilic vein and brachial artery as an A-V fistula for long term hemodialysis. J Surg Res. 1976;20:373-6.

9. Tordoir JH, Keuter X, Planken N, et al. Autogenous options in secondary and tertiary access for haemodialysis. Eur J Vasc Endovasc Surg. 2006;31:661-6.

10. Hill BB, Chan AK, Faruqi RM, et al. Keyhole technique for autologous brachiobasilic transposition arteriovenous fistula. J Vasc Surg. 2005;42:945-50.

11. Tordoir JH, Dammers R, de Brauw M. Video-assisted basilic vein transposition for haemodialysis vascular access: preliminary experience with a new technique. Nephrol Dial Transplant. 2001;16:391-4.

12. Kakkos SK, Haddad GK. Two-stage combined basilicbrachial vein transposition. Vascular. 2009;17:96-9.

13. Hastaoglu IO, Bilgen F. Basilic vein transposition performed for hemodialysis access: mid-term results [in Turkish]. Turkish J Thorac Cardiovasc Surg. 2011;19(4):513-7.

14. Ehsan O, Bhattacharya D, Darwish A, et al. 'Extension technique': a modified technique for brachio-cephalic fistula to prevent dialysis access-associated steal syndrome. Eur J Vasc Endovasc Surg. 2005;29:324-7.

15. Wu CC, Jiang H, Cheng J, et al. The outcome of the proximal radial artery arteriovenous fistula. J Vasc Surg. 2015;61:802-8. 
16. Sidawy AN, Gray R, Resarab A, et al. Recommended standards for reports dealing with arteriovenous hemodialysis access. J Vasc Surg. 2002;35:603-10.

17. Quinton W, Dillard D, Scribner BH. Cannulation of blood vessels for prolonged haemodialysis. Trans Am Soc Artif Intern Organs. 1960;6:104-13.

18. Brescia MJ, Cimino JE, Appel K, Hurwich BJ. Chronic haemodialysis using venipuncture and a surgically created arteriovenous fistula. N Engl J Med. 1966;275:108992.

19. Salahi H, Fazelzadeh A, Mehdizadeh A, et al. Complications of arteriovenous fistula in dialysis patients. Transplant Proc. 2006;38:1261-4.

20. Kaiser CL, Anaya-Ayala JE, Ismail N, et al. Unrecognized basilic vein variation leading to complication during basilic vein transposition arteriovenous fistula creation: case report and implications for access planning. Eur J Vasc Endovasc Surg. 2010;39:627-9.
21. Anaya-Ayala JE, Younes HK, Kaiser KL, et al. Prevalence of variant brachial-basilic vein anatomy and implications for vascular access planning. J Vasc Surg. 2011;53:720-4.

22. Scali ST, Huber TS. Treatment strategies for access-related hand ischemia. Semin Vasc Surg. 2011;24:128-36.

23. Papasavas PK, Reifsnyder T, Birdas TJ, et al. Prediction of arteriovenous access steal syndrome utilizing digital pressure measurements. Vasc Endovascular Surg. 2003;37:179-84.

24. Tan TW, Farber A. Brachial-basilic autogenous access. Sem Vasc Surg. 2011;24:63-71. 